\title{
Proinsulin, Insulin, and C-Peptide Concentrations in Human Portal and Peripheral Blood
}

\author{
David L. Horwitz, Jerome I. Starr, Mary E. Mako, William G. Blackard, and \\ Arthur H. Rubenstein \\ From the Department of Medicine, The University of Chicago Pritzker School \\ of Medicine, Chicago, Illinois 60637 and the Department of Medicine, \\ Louisiana State University Medical Center, New Orleans, Louisiana 70112
}

A B S T R A T Concentrations of insulin, proinsulin, and $\mathrm{C}$-peptide were measured in portal and peripheral venous blood in six nondiabetic, nonobese subjects. Portal vein samples were obtained by umbilical vein catheterization. Three subjects were studied with intravenous infusion of $25 \mathrm{~g}$ glucose, and three with $30 \mathrm{~g}$ arginine. Insulin and proinsulin were determined in the insulin immunoassay after separation by gel filtration, and $\mathrm{C}$-peptide was measured by direct immunoassay.

With both glucose and arginine stimulation, portal vein levels of all three peptides peaked at 90-120 s after the onset of the stimulus. Relative increases in insulin concentration were greater than those of proinsulin or C-peptide. In peripheral venous blood, maximal levels of the three peptides were observed later (2-5 min), and the increase in insulin relative to proinsulin and C-peptide was not as great. At the time of peak secretion, portal vein insulin and C-peptide approached equimolar concentrations, and proinsulin, as measured against an insulin standard, comprised approximately $2.5 \%$ of the total immunoreactive insulin.

After stimulation by glucose or arginine, portal insulin, proinsulin, and C-peptide levels were not correlated with the concentrations measured in simultaneously drawn peripheral samples. At all sampling times, however, significant correlation was found between insulin and $\mathrm{C}$-peptide in both peripheral and portal blood.

Portions of the work were presented at the 1974 Annual Meeting of the American Diabetes Association, and published in abstract form. (Horwitz, D. L., J. I. Starr, M. E. Mako, W. G. Blackard, and A. H. Rubenstein. 1974. Proinsulin, insulin, and C-peptide levels in portal and peripheral blood. Diabetes. 23 (Suppl. 1) : 350.)

Dr. Horwitz is a recipient of a Research and Development Award of the American Diabetes Association.

Received for publication 29 October 1974 and in revised form 3 February 1975.
The results indicate that under the conditions studied, insulin and $\mathrm{C}$-peptide are secreted in equimolar concentrations in man, and that proinsulin is secreted in the same proportion to insulin as found in the pancreas. Consideration of the relative secretory and metabolic rates of the three beta cell peptides explains their peripheral concentrations. The data further support the use of plasma C-peptide as an indicator of beta cell secretory function.

\section{INTRODUCTION}

It is now well established that insulin is synthesized as a precursor molecule, proinsulin, which is converted within the pancreatic beta cell to insulin. Insulin is then secreted together with the connecting peptide, or C-peptide, a 31 amino acid segment which forms the major portion of the link between the insulin A and B chains in the proinsulin molecule. Studies from several laboratories have demonstrated the value of measuring serum proinsulin and $\mathrm{C}$-peptide for both diagnostic and investigative purposes $(1,2)$. However, the hepatic extraction and peripheral metabolism of proinsulin, insulin, and C-peptide differ markedly in animals $(3,4)$, and peripheral vein concentrations do not necessarily reflect the relative rates at which these three peptides are secreted by pancreatic beta cells. We have therefore studied the relationship of portal and peripheral venous concentrations of insulin, proinsulin, and C-peptide in six nondiabetic subjects to determine whether peripheral levels may indeed be used as an indicator of their portal concentrations.

In addition, it has been noted that while insulin and C-peptide are secreted in equimolar amounts by isolated islets of Langerhans in vitro (5), molar concentrations of $\mathrm{C}$-peptide are significantly higher than 
TABLE I

Portal and Peripheral Venous Concentrations of Glucose, Insulin, Proinsulin, and C-Peptide Before, During, and After 2-min Infusion of $25 \mathrm{~g}$ Glucose

\begin{tabular}{|c|c|c|c|c|c|c|c|c|}
\hline \multirow[b]{2}{*}{ Time } & \multicolumn{2}{|c|}{ Glucose } & \multicolumn{2}{|c|}{ Insulin } & \multicolumn{2}{|c|}{ Proinsulin } & \multicolumn{2}{|c|}{ C-peptide } \\
\hline & Peripheral & Portal & Peripheral & Portal & Peripheral & Portal & Peripheral & Portal \\
\hline $\min$ & \multicolumn{2}{|c|}{$\mathrm{mg} / 100 \mathrm{ml}$} & \multicolumn{2}{|c|}{$n g / m l$} & \multicolumn{2}{|c|}{$n g / m l$} & \multicolumn{2}{|c|}{$n g / m l$} \\
\hline-1 & $85 \pm 5$ & $83 \pm 9$ & $0.36 \pm 0.21$ & $0.97 \pm 0.16$ & $0.19 \pm 0.08$ & $0.31 \pm 0.11$ & $3.64 \pm 1.54$ & $4.35 \pm 1.42$ \\
\hline 0 & $80 \pm 6$ & $80 \pm 10$ & $0.36 \pm 0.21$ & $1.13 \pm 0.67$ & $0.24 \pm 0.18$ & $0.34 \pm 0.10$ & $3.54 \pm 1.05$ & $4.96 \pm 2.31$ \\
\hline 1 & $92 \pm 4$ & $182 \pm 32$ & $0.48 \pm 0.12$ & $16.60 \pm 10.08$ & $0.43 \pm 0.05$ & $1.66 \pm 0.66$ & $3.72 \pm 1.75$ & $16.64 \pm 3.39$ \\
\hline 1.5 & $164 \pm 33$ & $249 \pm 12$ & $0.38 \pm 0.20$ & $25.13 \pm 7.27$ & $0.42 \pm 0.06$ & $2.12 \pm 0.72$ & $3.03 \pm 0.86$ & $18.73 \pm 7.40$ \\
\hline 2 & $218 \pm 49$ & $284 \pm 28$ & $0.66 \pm 0.20$ & $19.23 \pm 10.10$ & $0.61 \pm 0.09$ & $1.82 \pm 1.06$ & $4.36 \pm 1.70$ & $11.86 \pm 6.43$ \\
\hline 2.5 & $247 \pm 35$ & $338 \pm 22$ & $1.42 \pm 0.19$ & $12.93 \pm 4.58$ & $0.72 \pm 0.04$ & $1.58 \pm 0.55$ & $5.43 \pm 0.34$ & $9.38 \pm 2.27$ \\
\hline 3 & $266 \pm 16$ & $333 \pm 17$ & $2.10 \pm 0.08$ & $8.77 \pm 2.61$ & $0.68 \pm 0.13$ & $1.25 \pm 0.56$ & $7.09 \pm 0.81$ & $8.22 \pm 2.26$ \\
\hline 5 & $232 \pm 4$ & $269 \pm 9$ & $2.73 \pm 0.33$ & $5.48 \pm 1.72$ & $0.52 \pm 0.19$ & $0.76 \pm 0.41$ & $7.61 \pm 0.04$ & $9.08 \pm 1.79$ \\
\hline 7 & $211 \pm 2$ & $244 \pm 6$ & $1.92 \pm 0.96$ & $4.81 \pm 2.11$ & $0.65 \pm 0.01$ & $0.80 \pm 0.17$ & $5.82 \pm 3.71$ & $9.51 \pm 2.21$ \\
\hline 10 & $207 \pm 8$ & $225 \pm 4$ & $1.73 \pm 0.76$ & $4.92 \pm 1.76$ & $0.56 \pm 0.22$ & $1.03 \pm 0.32$ & $6.35 \pm 1.53$ & $9.09 \pm 2.33$ \\
\hline 12 & $194 \pm 5$ & $202 \pm 5$ & $1.88 \pm 0.90$ & $5.20 \pm 2.42$ & $0.67 \pm 0.22$ & $0.76 \pm 0.35$ & $6.97 \pm 1.49$ & $9.22 \pm 2.60$ \\
\hline 17 & $190 \pm 3$ & $205 \pm 12$ & $1.47 \pm 0.84$ & $4.90 \pm 1.73$ & $0.58 \pm 0.20$ & $0.94 \pm 0.37$ & $7.23 \pm 1.37$ & $10.43 \pm 3.37$ \\
\hline
\end{tabular}

Results are means $\pm \mathrm{SD}$.

those of insulin in the peripheral circulation (6). Similarly, the ratio of proinsulin to insulin in venous blood greatly exceeds that found in the pancreas (7). Measurement of portal vein concentrations of these peptides in man has enabled us to determine the basis for these findings.

\section{METHODS}

Six nondiabetic subjects requiring elective abdominal surgery were studied. The procedure of portal vein catheterization was explained in detail to each patient and their option to decline was stressed. Informed written consent was obtained from each patient. The experiments had been approved by the human experimentation committees of both the medical school and the hospital at which these studies were conducted. Surgery was required for either duodenal ulcer disease or chronic cholecystitis. No subject was obese, but some had lost a small amount of weight before surgery. All had normal tests of hepatic function, and fasting and postprandial blood glucose levels were within the normal range.

After an overnight fast, the patients were prepared for abdominal exploration. No general anesthetic was given, but some subjects received $5 \mathrm{mg}$ diazepam (Valium, Roche Laboratories, Div. of Hoffmann-La Roche, Nutley, N. J.) or $50 \mathrm{mg}$ meperidine (Demerol, Breon Laboratories, Inc., New York) before the procedure. A catheter for withdrawal of blood samples was placed in an antecubital vein and kept patent by saline infusion. Under sterile conditions, with local anesthesia with $1 \%$ Xylocaine (Astra Pharmaceutical Products, Inc., Worcester, Mass.), the umbilical vein was exposed and cannulated. The catheter was passed into the left branch of the portal vein immediately distal to its entrance into the liver. Details of the procedure have been published (8). After the study, all patients had the planned laparotomy performed under general anesthesia.

Three subjects were given an infusion of $25 \mathrm{~g}$ glucose over $2 \mathrm{~min}$ into a peripheral vein. Two base-line samples were obtained before the administration of glucose, and further samples were taken at 60,90 , and $120 \mathrm{~s}$ after the start of the infusion and at 1, 3, 5, 8, 10, and $15 \mathrm{~min}$ after its completion. The other three subjects were given $30 \mathrm{~g}$ arginine (as a $10 \%$ solution) at a rate of $2 \mathrm{~g} / \mathrm{min}$ for 15 min. Samples were obtained at $-1,0, \frac{1}{2}, 1,1 \frac{1}{2}, 2,3,5,8$, $10,15,17$, and $20 \mathrm{~min}$ after the onset of infusion.

Total serum insulin (IRI) ${ }^{1}$ was determined by the double-antibody method of Morgan and Lazarow (9). C-peptide immunoreactivity (CPR) was measured by a previously described immunoassay (10), with a rabbit antiC-peptide antiserum prepared against synthetic human Cpeptide (kindly supplied by Dr. Norboru Yanaihara of Shizuoka College of Pharmacy, Shizuoka-shi, Japan). Proinsulin cross-reacts in this assay about $1 / 15$ as well as Cpeptide, and the relative concentrations of serum $\mathrm{C}$-peptide and proinsulin are such that less than $3 \%$ of measured $\mathrm{C}$ peptide could be attributed to proinsulin. Sera were separated on Bio-Gel P-30 columns (Bio-Rad Laboratories, Richmond, Calif.) equilibrated in borate buffer at $\mathrm{pH} 8.0$ and the immunoreactive insulin-like activity in each fraction was determined by the insulin assay. Two well-separated peaks, corresponding to the proinsulin-like components (first peak), PLC, ${ }^{1}$ and insulin (second peak), were found. By using standards of human proinsulin and insulin, the absolute amounts of each peptide in the original serum could be calculated by summing the values obtained in the PLC fractions (read against the proinsulin standard) and those in the insulin region (read from the insulin standard) (11). The proportion of insulin immunoreactivity due to proinsulin was calculated by expressing the sum of the proinsulin fractions, measured against the insulin standard, as a percentage of the total immunoreactive insulin concentration in all the fractions. Glucose was measured in whole blood by a glucose oxidase method (12).

Standard statistical methods were used to calculate product-moment correlation coefficients and linear least-squares regression equations (13).

${ }^{1}$ Abbreciations used in this paper: CPR, C-peptide immunoreactivity; IRI, total immunoreactive insulin; PLC, proinsulin-like components. 


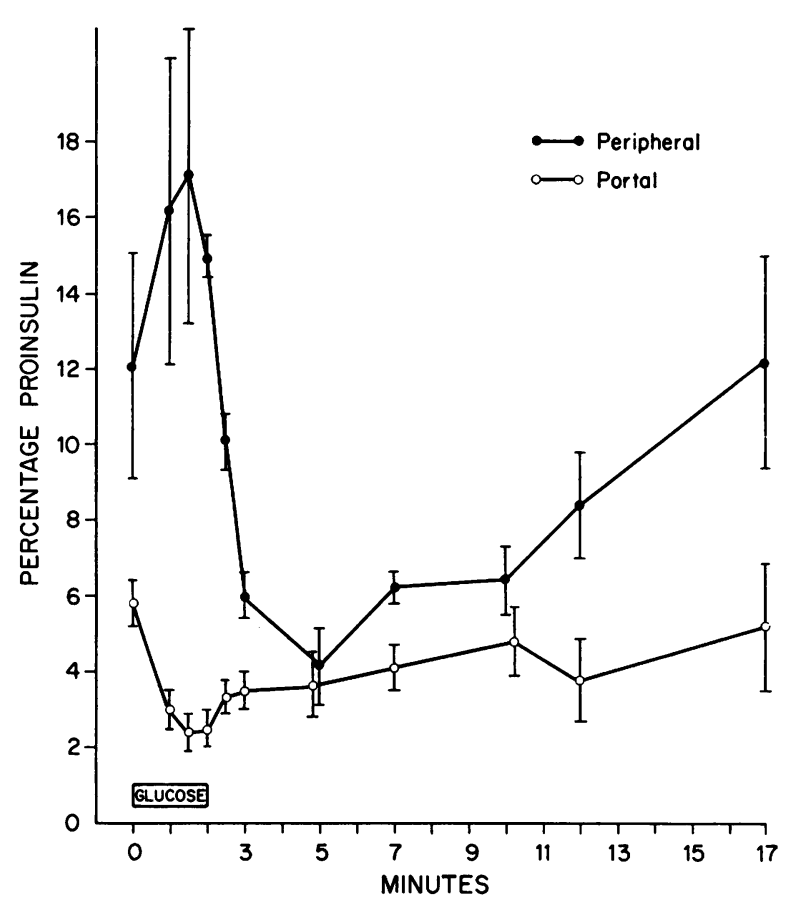

FIGURE 1 Proinsulin component of immunoreactive insulin (IRI) expressed as a percentage of total IRI (mean \pm SEM). Values shown are the proinsulin component, determined after gel filtration and assayed against an insulin standard. Samples were obtained before, during, and after a 2-min, $25 \mathrm{~g}$ glucose infusion.

\section{RESULTS}

Glucose infusion. Values obtained during the glucose infusion are given in Table I. In the portal vein, insulin, PLC, and C-peptide reach maximal concentrations within $90 \mathrm{~s}$ after the onset of the infusion. The

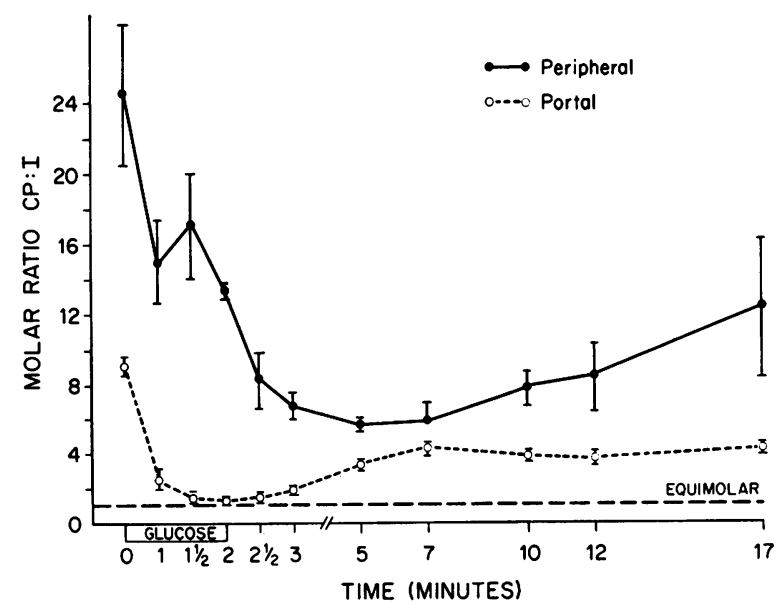

FIGURE 2 C-peptide: insulin molar ratios in portal and peripheral blood (mean \pm SEM). Samples were taken before, during, and after a glucose infusion as in Fig. 1. The dashed line indicates the theoretical equimolar ratio.
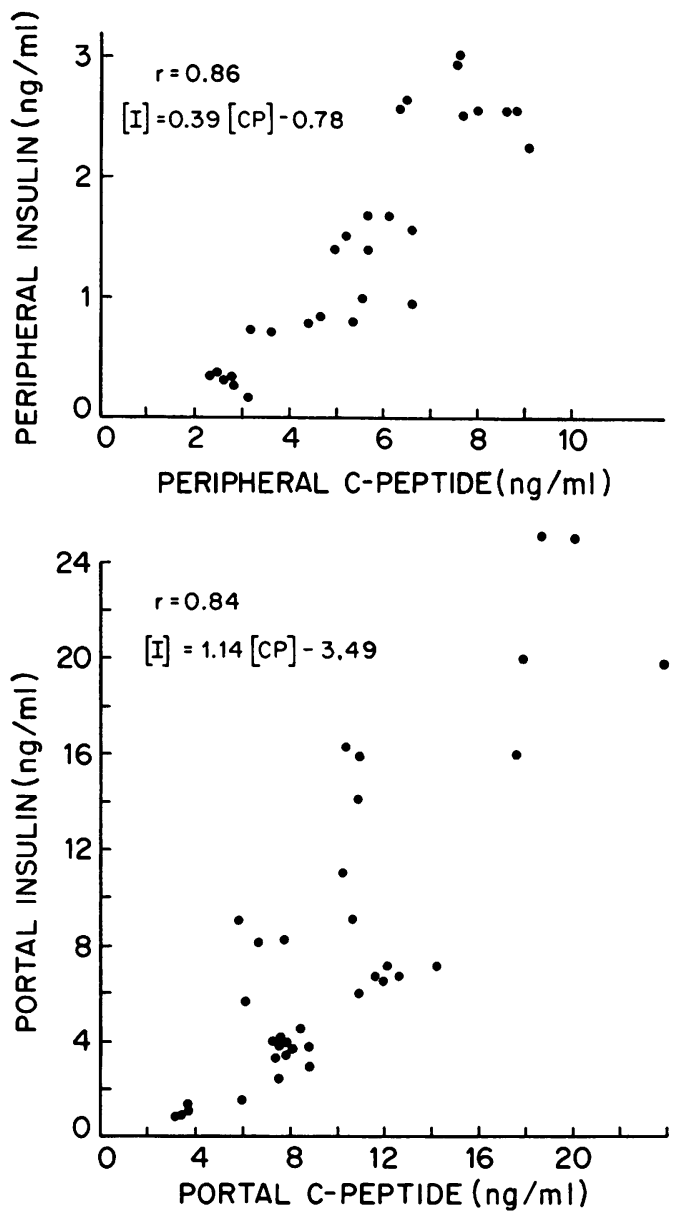

FIGURE 3 Correlation between insulin and C-peptide concentrations, in both portal and peripheral blood, during and after glucose infusions in the three subjects. Productmoment correlation coefficients $(r)$ and least-squares regression equations are shown.

relative increases, however, were of different magnitude, with insulin showing a 14-fold rise, PLC a 6-fold increase, and C-peptide rising by a factor of four. In the peripheral circulation, peak levels occurred somewhat later, between 2 and $5 \mathrm{~min}$. The increase in insulin was sevenfold, in PLC threefold, and in C-peptide twofold. These results indicated that while the three peptides were secreted in parallel, there were quantitative differences in their degree of rise.

Fig. 1 shows the percentage of serum immunoreactive insulin-like activity contributed by PLC. In the portal vein, there is a decline from basal values of $6 \%$ to $2.5 \%$ at the time of peak secretion. After the end of the glucose infusion, there was a gradual return to basal levels. A similar pattern is seen in peripheral blood, but the time course is slower and the percentage of PLC is higher.

The molar ratios of $\mathrm{C}$-peptide to insulin during the glucose infusion are shown in Fig. 2. The values were 
TABLE II

Portal and Peripheral Venous Concentrations of Glucose, IRI, and C-Peptide before, during, and after 15-min Infusion of $30 \mathrm{~g}$ Arginine

\begin{tabular}{|c|c|c|c|c|c|c|}
\hline \multirow[b]{2}{*}{ Time } & \multicolumn{2}{|c|}{ Glucose } & \multicolumn{2}{|c|}{ IRI } & \multicolumn{2}{|c|}{ C-peptide } \\
\hline & Peripheral & Portal & Peripheral & Portal & Peripheral & Portal \\
\hline $\min$ & \multicolumn{2}{|c|}{$\mathrm{mg} / 100 \mathrm{ml}$} & \multicolumn{2}{|c|}{$n g / m l$} & \multicolumn{2}{|c|}{$n g / m l$} \\
\hline-1 & $90 \pm 6$ & $88 \pm 3$ & $0.8 \pm 0.4$ & $2.8 \pm 2.0$ & $4.3 \pm 2.0$ & $6.5 \pm 2.6$ \\
\hline 0 & $82 \pm 4$ & $85 \pm 2$ & $0.8 \pm 0.5$ & $3.0 \pm 1.5$ & $4.4 \pm 1.7$ & $6.5 \pm 3.8$ \\
\hline 0.5 & $83 \pm 18$ & $84 \pm 8$ & $1.0 \pm 0.4$ & $6.2 \pm 2.5$ & $5.7 \pm 0.2$ & $9.4 \pm 0.1$ \\
\hline 1 & $84 \pm 11$ & $91 \pm 13$ & $0.8 \pm 0.3$ & $29.4 \pm 6.2$ & $4.4 \pm 1.7$ & $18.1 \pm 7.5$ \\
\hline 1.5 & $78 \pm 17$ & $84 \pm 8$ & $1.3 \pm 0.1$ & $23.3 \pm 6.7$ & $6.2 \pm 0.1$ & $18.9 \pm 3.3$ \\
\hline 2 & $81 \pm 21$ & $82 \pm 6$ & $2.1 \pm 0.9$ & $31.6 \pm 14.8$ & $6.9 \pm 0.2$ & $17.6 \pm 2.5$ \\
\hline 3 & $85 \pm 19$ & $93 \pm 8$ & $3.2 \pm 3.7$ & $18.7 \pm 2.2$ & $6.4 \pm 3.7$ & $12.9 \pm 4.4$ \\
\hline 5 & $89 \pm 16$ & $95 \pm 10$ & $4.0 \pm 2.7$ & $8.3 \pm 2.8$ & $6.4 \pm 2.1$ & $9.3 \pm 2.6$ \\
\hline 8 & $87 \pm 16$ & $97 \pm 12$ & $3.4 \pm 1.9$ & $8.5 \pm 6.4$ & $6.6 \pm 1.4$ & $9.0 \pm 4.2$ \\
\hline 10 & $84 \pm 12$ & $102 \pm 12$ & $2.9 \pm 1.8$ & $11.7 \pm 6.4$ & $6.4 \pm 1.8$ & $9.0 \pm 3.4$ \\
\hline 12 & $99 \pm 20$ & $102 \pm 11$ & $3.5 \pm 2.3$ & $12.5 \pm 4.6$ & $6.6 \pm 2.0$ & $11.6 \pm 3.2$ \\
\hline 15 & $91 \pm 9$ & $105 \pm 11$ & $4.1 \pm 2.7$ & $12.8 \pm 2.5$ & $6.9 \pm 2.0$ & $10.7 \pm 2.5$ \\
\hline 17 & $94 \pm 12$ & $108 \pm 16$ & $4.0 \pm 1.8$ & $13.6 \pm 2.9$ & $8.4 \pm 3.1$ & $12.5 \pm 4.5$ \\
\hline 20 & $97 \pm 15$ & $111 \pm 14$ & $4.5 \pm 2.9$ & $14.1 \pm 3.2$ & $7.8 \pm 2.6$ & $13.6 \pm 3.7$ \\
\hline
\end{tabular}

Results are means $\pm \mathrm{SD}$.

calculated from the ratios of each individual subject on the basis of molecular weights of 3,021 for C-peptide and 5,807 for insulin. In the basal state, both peripheral and portal $\mathrm{C}$-peptide are present in molar concentrations well above those of insulin. The C-peptide: insulin ratio falls during the period of increased insulin secretion and reaches a value of $1.17 \pm 0.06$ in the portal vein at $2 \mathrm{~min}$, closely approximating equimolarity. After the glucose infusion, the molar ratio rises toward basal levels.

Peripheral insulin and C-peptide concentrations correlate well with each other, as do those of portal vein insulin and $\mathrm{C}$-peptide. The data are shown in Fig. 3, the insulin: C-peptide correlation coefficients being 0.86 in peripheral blood and 0.84 in portal blood.

Arginine infusion. The glucose. IRI, and CPR values obtained during the arginine infusion are shown in Table II. In this study, the IRI was not fractionated into insulin and PLC. The pattern is similar to that observed during the glucose infusion, in that the very rapid rise in portal concentrations is not reflected in the peripheral values, and the relative increases in portal concentrations are approximately twice those seen in the periphery. Insulin-C-peptide correlation coefficients were 0.75 in peripheral and 0.82 in portal blood.

The molar ratio of $\mathrm{C}$-peptide to insulin after arginine showed a pattern similar to that during the glucose infusion. In particular, at the time of peak C-peptide levels, the mean portal vein CPR:IRI ratio was close to equimolarity $(1.07 \pm 0.06)$.

\section{DISCUSSION}

Peripheral insulin concentrations are frequently interpreted as reflecting panceatic secretion of the hormone. However, because the liver has been shown to be the most important organ for removal of insulin from the circulation $(14,15)$, studies of simultaneously obtained portal and peripheral blood samples have been carried out to determine how well peripheral levels reflect those in the portal vein $(8,16-19)$. The results of these previous studies have indicated that while portal and peripheral values generally correlate with each other, significant quantitative differences do occur. Furthermore, Blackard and Nelson (8) have shown that certain qualitative features of the secretory pattern observed in the portal vein are not seen when peripheral concentrations are measured. Because C-peptide has been proposed as an indicator of beta cell secretory function (6) in patients whose endogenous insulin cannot be measured, such as a diabetic patient receiving injections of therapeutic insulin or with circulating insulin antibodies, it is important to determine how its peripheral and portal vein concentrations are related. Similarly, measurement of peripheral venous PLC has been useful in the diagnosis of insulin-secreting tumors of the pancreas $(20,21)$ and knowledge of the relationship between its portal and peripheral levels would be helpful in the interpretation of these values.

Statistically significant correlations between portal and peripheral values of the three peptide concentrations could be shown during the base-line period and the late 
poststimulatory (3-17 $\mathrm{min}$ ) period after glucose (when correlation coefficients between portal and peripheral levels were 0.87 for insulin, 0.89 for C-peptide, and 0.84 for PLC). However, no linear relationship between the portal and peripheral concentrations was seen during the stimulatory period $(0-2.5 \mathrm{~min})$, or when data from the entire study period were analysed together. The poor correlation was probably due to the large dilutional factor in passing from portal to systemic circulation, and the delay in transit through the liver. The portal and peripheral IRI and C-peptide concentrations were even less well correlated after arginine than after glucose. The cause of this additional disparity between the portal-peripheral correlations in the arginine test is not immediately apparent, but at least three explanations should be considered. First, it is possible that arginine differentially affects the hepatic uptake of insulin and $\mathrm{C}$-peptide in a way that glucose does not. Second, the portal vein levels show a biphasic pattern that is not as marked in the peripheral values. Third, since the insulin concentrations in the portal vein were higher during the arginine than the glucose infusion, there may be a relatively greater hepatic extraction of insulin compared to $\mathrm{C}$-peptide during the arginine infusion. This latter possibility is compatible with the results of Waddell and Sussman (22) and Kaden, Harding, and Field (23), who found that a rise in pancreatic insulin secretion (induced by glucose in the cited experiments) was associated with an increase in the hepatic extraction of the hormone. On the other hand, some studies suggest no change (24) or a decrease (25) in hepatic removal of insulin as the portal level rises. Because of this uncertainty, and the variable relationship of portal and peripheral insulin, it appears that the peripheral C-peptide concentrations may under certain circumstances provide a more reliable picture of beta cell secretion than does the peripheral insulin level. Furthermore, the close correlation between portal insulin and $\mathrm{C}$-peptide levels, and between peripheral insulin and $\mathrm{C}$-peptide, indicate that $\mathrm{C}$-peptide concentrations may be used as an indicator of insulin levels in both portal and peripheral blood in situations where it is difficult to measure insulin itself.

The proinsulin content of extracted pancreas is less than $7 \%$ of the immunoreactive insulin level (26-32), while basal values in peripheral blood are higher, comprising approximately $20 \%$ of total IRI $(7,33-36)$. Although it has been suggested that the higher circulating proinsulin content indicates preferential release of newly formed granules, which contain a higher proportion of proinsulin, our data on portal vein blood indicate that the ratio of proinsulin to insulin being secreted is similar to that present in the pancreas. These results are compatible with random release of insulin granules from the beta cell, there being no preference for either newly formed or more mature granules under ordinary conditions (28). Proinsulin is more slowly catabolized than insulin in animals $(3,4)$, and in man the half-time of disappearance of endogenous proinsulin is $17.2 \mathrm{~min}$, compared to $4.8 \mathrm{~min}$ for insulin (37). The results in Fig. 1 may therefore be explained as follows. In the portal vein, the percentage of proinsulin in the basal state is higher than that in the pancreas, because of the accumulation of the more slowly catabolized proinsulin. At the time of maximal secretion, when absolute levels are high compared to basal values, recirculating proinsulin is of less quantitative significance, and the percentage of proinsulin in the portal vein declines to reach values present in the pancreas. At later times, as beta cell secretion diminishes, there is a gradual return to the higher basal levels, which may be attributed again to the relatively greater persistance of proinsulin as compared with insulin. The pattern in peripheral blood is essentially similar. However, the time course of the changes is slower and the percentage of proinsulin is higher, because hepatic extraction of insulin is greater than that of proinsulin.

The molar concentrations of serum-C-peptide are substantially greater than insulin in healthy subjects $(6,10)$, although theoretical considerations and in vitro experiments suggest equimolar secretion (5). This discrepancy apparently arises because C-peptide is more slowly catabolized than insulin (3), having a $t_{1}$ of 11.1 min compared to $4.8 \mathrm{~min}$ for insulin in $\operatorname{man}(38)$. The results shown in Fig. 2 support this interpretation, for at times of peak secretion, when portal vein levels far exceed basal values, the two peptides are indeed present in nearly equimolar concentrations. In the peripheral circulation, the molar ratio of C-peptide to insulin always exceeds unity, implying substantially greater hepatic extraction of insulin than $\mathrm{C}$-peptide. This conclusion is compatible with the observations of Katz and Rubenstein (3), who showed that C-peptide in rats is predominantly metabolized by the kidney, in contrast to the predominantly hepatic metabolism of insulin. Different dilution volumes of insulin and $C$-peptide could potentially account for some of the observations, but data on this point are not available.

\section{ACKNOWLEDGMENTS}

This work has been supported by grants from the U. S. Public Health Service (AM 13,941), the Louis Block Fund of the University of Chicago, and the Bertha and Henry Brownstein Foundation. Portions of this work were sponsored by the U. S. Public Health Service Diabetes Center (AM 17,046) at the University of Chicago.

\section{REFERENCES}

1. Rubenstein, A. H., M. B. Block, J. Starr, F. Melani, and D. F. Steiner. 1972. Proinsulin and C-peptide in blood. Diabetes. 21 (Suppl. 2) : 661-672. 
2. Kitabchi, A. E. 1972. Clinical significance of proinsulin in human plasma. South. Mcd. J. 65: 833-838.

3. Katz, A. I., and A. H. Rubenstein. 1973. Metabolism of proinsulin, insulin, and C-peptide in the rat. J. Clin. Invest. 52: 1113-1121.

4. Rubenstein, A. H., L. A. Pottenger, M. Mako, G. S. Getz, and D. F. Steiner. 1972. The metabolism of proinsulin and insulin by the liver. J. Clin. Invest. 51: 912921.

5. Rubenstein, A. H., J. L. Clark, F. Melani, and D. F. Steiner. 1969. Secretion of proinsulin C-peptide by pancreatic $\beta$ cells and its circulation in blood. Nature (Lond.). 224: 697-699.

6. Block, M. B., M. E. Mako, D. F. Steiner, and A. H. Rubenstein. 1972. Circulating C-peptide immunoreactivity. Studies in normals and diabetic patients. Diabctes. 21: 1013-1026.

7. Melani, F., A. H. Rubenstein, and D. F. Steiner. 1970. Human serum proinsulin. J. Clin. Invest. 49: 497-507.

8. Blackard, W. G., and N. C. Nelson. 1970. Portal and peripheral vein immunoreactive insulin concentrations before and after glucose infusion. Diabetes. 19: 302-306.

9. Morgan, C. R., and A. Lazarow. 1963. Immunoassay of insulin: two antibody system. Plasma levels of normal, subdiabetic and diabetic rats. Diabetcs. 12: 115-126.

10. Melani, F., A. H. Rubenstein, P. E. Oyer, and D. F. Steiner. 1970. Identification of proinsulin and C-peptide in human serum by a specific immunoassay. Proc. Natl. Acad. Sci. U. S. A. $67: 148-155$.

11. Starr, J. I., and A. H. Rubenstein. 1974. Insulin, proinsulin and C-peptide. In Methods of Hormone Radioimmunoassay. B. M. Jaffe and H. R. Behrman, editors. Academic Press, Inc., New York. 289-315.

12. Saifer, A., and S. Gerstenfeld. 1958. The photometric microdetermination of blood glucose with glucose oxidase. J. Lab. Clin. Med. 51: 448-460.

13. Sokal, R. R., and F. J. Rohlf. 1969. Biometry. The Principles and Practice of Statistics in Biological Research. W. H. Freeman and Company, Publishers, San Francisco, Calif. 498-508.

14. Samols, E., and J. A. Ryder. 1961. Studies on tissue uptake of insulin in man using a differential immunoassay for endogenous and exogenous insulin. J. Clin. Invest. 40: 2092-2102.

15. Kanazawa, Y., T. Kuzuya, T. Ide, and K. Kosaka. 1966. Plasma insulin responses to glucose in femoral hepatic, and pancreatic veins in dogs. Am. J. Physiol. 211: 442-448.

16. Blackard, W. G., and N. C. Nelson. 1971. Portal and peripheral vein immunoreactive insulin concentrations following tolbutamide administration. Diabetes. 20: 168170.

17. Erwald, R., R. Hed, A. Hygren, S. Röjdmark, L. Sundblad, and K.-L. Wiechel. 1971. Immunoreactive insulin in the portal and peripheral venous blood after intravenous tolbutamide administration. Diabetes. 20 : 686-690.

18. Erwald, R., R. Hed, A. Nygren, S. Röjdmark, L. Sundblad, and K.-L. Wiechel. 1973. Insulin concentration in portal and peripheral venous blood after oral glucose in human pancreatitis. Acta Med. Scand. 194: 103-109.

19. Berger, W., H. Göschke, J. Moppert, and H. Künzli. 1973. Insulin concentrations in portal venous and peripheral vencus blood in man following administration of glucose, galactose, xylitol, and tolbutamide. Horm. Metab. Res. 5: 4-8.
20. Rubenstein, A. H., M. E. Mako, J. I. Starr, D. J. Juhn, and D. L. Horwitz. 1974. Circulating proinsulin in patients with islet cell tumors. Exccrpta Med. Int. Congr. Ser. 312: 736-752.

21. Schein, P. S., R. A. DeLellis, C. R. Kahn, P. Gorden, and A. R. Kraft. 1973. Islet cell tumors: current concepts and management. Ann. Intern. Mcd. 79: 239-257.

22. Waddell, W. R., and K. E. Sussman. 1967. Plasma insulin after diversion of portal and pancreatic venous blood to vena cava. J. Appl. Phy'siol. 22: 808-812.

23. Kaden, M., P. Harding, and J. B. Field. 1973. Effect of intraduodenal glucose administration on hepatic extraction of insulin in the anesthetized dog. J. Clin. Invest. 52: 2016-2028

24. Kaplan, N., and L. L. Madison. 1959. Effects of endogenous insulin secretion on the magnitude of hepatic binding of labeled-insulin during a single transhepatic circulation in human subjects. Clin. Res. 7: 248.

25. Samols, E., and J. A. Ryder. 1961. Studies on tissue uptake of insuliin in man using a differential immunoassay for endogenous and exogenous insulin. J. Clin. Invest. 40 : 2092-2102.

26. Rastogi, G. K., J. Letarte, and T. R. Fraser. 1970. Proinsulin content of pancreas in human fetuses of healthy mothers. Lancet. 1: 7-9.

27. Chance, R. E., and R. M. Ellis. 1969. Proinsulin. Singlechain precursor of insulin. Arch. Intern. Med. 123: 229-236.

28. Sando, H., J. Borg, and D. F. Steiner. 1972. Studies on the secretion of newly synthesized proinsulin and insulin from isolated rat islets of Langerhans. J. Clin. Invest. 51 : 1476-1485.

29. Rastogi, G. K., M. K. Sinha, and R. J. Dash. 1973 Insulin and proinsulin content of pancreases from diabetic and non-diabetic subjects. Diabetes. 22: 804-807.

30. Burr, I. M., W. Stauffacher, L. Balant, A. E. Renold, and G. Grodsky. 1969. Dynamic aspects of proinsulin release from perifused rat pancreas. Lancet. 2: 882-883.

31. Gutman, R. A., G. Fink, J. R. Shapiro, H. Selawry, and L. Recant. 1973. Proinsulin and insulin release with a human insulinoma and adjacent nonadenomatous pancreas. J. Clin. Endocrinol. Metab. 36: 978-987.

32. Lockwood, D. H., and R. I. Misbin. 1972. Proinsulin content of adult and fetal pancreatic tissue extracted after rapid freezing in situ. Horm. Metab. Res. 4: 232234.

33. Goldsmith, S. J., R. S. Yalow, and S. A. Berson. 1969. Significance of human plasma insulin Sephadex fractions. Diabetes. 18: 834-839.

34. Gutman, R. A., N. R. Lazarus, J. C. Penhos, S. Fajans, and L. Recant. 1971. Circulating proinsulin-like material in patients with functioning insulinomas. N. Engl. J. Med. 284: 1003-1008.

35. Sherman, B. M., S. Pek, S. S. Fajans, J. C. Floyd, Jr., and J. W. Conn. 1972. Plasma proinsulin in patients with functioning pancreatic islet cell tumors. J. Clin. Endocrinol. Mctab. 35: 271-280.

36. Gorden, P., B. Sherman, and J. Roth. 1971. Proinsulinlike component of circulating insulin in the basal state and in patients and hamsters with islet cell tumors. $J$. Clin. Invest. 50: 2113-2122.

37. Starr, J. I., and A. H. Rubenstein. 1974. Metabolism of endogenous proinsulin and insulin in man. J. Clin. Endocrinol. Mctab. 38: 305-308.

38. Horwitz, D. L., J. I. Starr, A. H. Rubenstein, and D. F. Steiner. 1973. Serum connecting peptide-an indicator of beta cell secretory function. Diabetes. 22 (Suppl. 1) : 298 (Abstr) 